\title{
Protection of Chocolate Products from Indian Meal Moth by Adding Cinnamon Extract to the Adhesive on the Wrapping
}

\author{
Ja Hyun $\mathrm{Na}$, Euk II Hong ${ }^{1}$ and Mun II Ryoo* \\ Division of Environmental Science and Ecological Engineering, College of Life Science and Biotechnology, Korea University, Seongbuk-Gu, \\ Seoul, 136-701, Korea \\ ${ }^{1}$ Crown Confectionery Co. LTD., 1337-31 Seocho-Dong, Seocho-Gu, Seoul, 137-070, Korea
}

\begin{abstract}
Adding cinnamon (Cinnamonum cassia Blume) extract into the adhesive used to affix stickers to a chocolate package is an effective method for protecting chocolate products from infestation by the Indian meal moth (Plodia interpunctella Hübner). Chocolate packages treated with adhesive including $0.02 \%$ and $0.025 \%$ of cinnamon extract were not infested with the Indian meal moth for up to 30 days at $28.1^{\circ} \mathrm{C}$ and $70-75 \% \mathrm{RH}$, whereas $100 \%$ of the packages without the extract were infested in the no-choice test. Chocolate packages treated with adhesive including $0.02 \%$ and $0.025 \%$ of cinnamon extract in the quadruple choice test were not infested with the Indian meal moth for up to 60 days at $28.1^{\circ} \mathrm{C}$ and $70-75 \% \mathrm{RH}$, whereas $100 \%$ of the packages without the extract were infested. A panel test showed that the cinnamon extract treatment would not affect consumers' choices.
\end{abstract}

KEY WORDS : Chocolate Package, Cinnamon extract, Indian meal moth, Cinnamonum cassia bark

초 록 : 초콜렛 포장에 스티커를 붙이기 위해 사용되는 접착물에 계피(Cinnamonum cassia Blume) 추출물을 혼합하는 것은 화랑곡나방(Plodia interpunctella Hübner)에 의한 침입으로부터 초콜렛 제품을 보호하기 위한 효과적인 한 방법이다. 처리농도별 제품을 개별적으로 투입한 비선택 실험에서 0.02 와 $0.025 \%$ 의 계피 추출물을 처리한 포장지로 포장된 초콜렛 제품은 $28.1{ }^{\circ} \mathrm{C}$ 와 $70-75 \%$ 의 실험 조건에서 30 일까지 화랑곡나방이 침입하지 않았으나, 계피 추출물이 첨가되지 않은 포장은 화랑곡나방에 의해 침입되었다. 처리농도별 제품을 혼합 투입한 선택 실험에서 0.02 와 $0.025 \%$ 의 계피 추출물을 처리한 포장지로 포장된 초콜렛 제품은 $28.1^{\circ} \mathrm{C}$ 와 $70-75 \%$ 의 실험 조건에서 60 일까지 화랑곡나방에 의해 침입받지 않았는데 반해, 계피 추출물이 첨가되지 않은 제품은 화랑곡나방에 의해 침입을 받았다. 제품의 계피향 흡착 유무를 알아보기 위해 실시한 패널 테스트 결과 포장지에 계피 추출물을 처리하여도 제품에 향이 흡착되지 않아 소비자의 선택에 영향을 미치지 않을 것이라 판단되었다.

검색어 : 초콜렛 포장, 계피 추출물, 화랑곡나방, Cinnamonum cassia bark

Chocolate has a unique taste, and is rich in nutrients and a favorite food commodity in Korea, as elsewhere. The chocolate markets occupy for $14 \%$ of the confectionery markets, and is estimated to be worth 500 million dollars annually in Korea. The majority of chocolate products are sold as packaged material, and package and chocolate designs both perform a significant function in attracting consumers. External packaging is also a major physical barrier that protects chocolate against insect infestation. It is important because insect

*Corresponding author. E-mail: ryoomi@korea.ac.kr 
infestation of chocolate is the cause of most consumer complaints, and spoils the image of manufacturers. Korean manufacturers have continued to search for chocolate packaging that is attractive to consumers and has a minimum risk of insect infestation. Materials utilized for the packaging of chocolate include aluminum foil, composite films, and paper or plastic trays (Begum et al., 2007); these evidence differing resistance to insect infestation (Cline, 1978; Highland, 1984; Newton, 1988). In an effort to improve insect resistance, the treatment of the materials with repellents such as pyrethrins and methyl salicinate has been previously proposed (Watson and Barson, 1996; Mullen and Mowery, 2000; Redwan and Allin, 1997). However, this is a nuisance to all chocolate consumers ( $\mathrm{Na}$ and Hong, personal observation), even though these repellents are approved for packaging treatment in the USA (Highland, 1991). In many recent studies, it has been shown that herb extracts and plant oils evidence insecticidal activities and could be used to control insects in stored products (Cline, 1978; Shaaya et al., 1997; Huang and Ho, 1998; Field et al., 2001). It is a safe and effective methods for protecting insect infestation is a treatment of chocolate packaging with herb extracts or oils rater than the use of chemicals.

We describe our feasibility study on the use of Cinnamonum cassia Blume extracts to treat chocolate packaging to protect chocolate products from infestation by the Indian meal moths (Plodia interpunctella Hübner) in the retail markets. The Indian meal moths are the principal pests of chocolate in Korea (E. L. Hong, personal observation).

\section{Materials and Methods}

The chocolate package tested in this study is used in the best selling chocolate product on the Korean retail market. Five pieces $(28 \times 28 \times 10 \mathrm{~mm})$ of milk chocolate contained milk solids, cocoa solids, and sugar etc. with inside aluminum-coated paper (the inner layer). The chocolate peaces were placed on a paper pad $(28 \times 140 \times 10$ $\mathrm{mm}$ ), upon which a picture sticker was fixed, and were packed with a cellophane outer layer (Fig. 1). A chocolate piece weighed $6.78 \mathrm{~g}$, and the moisture content of the chocolate was less than $1 \%$.

Indian meal moths were maintained for more than 10

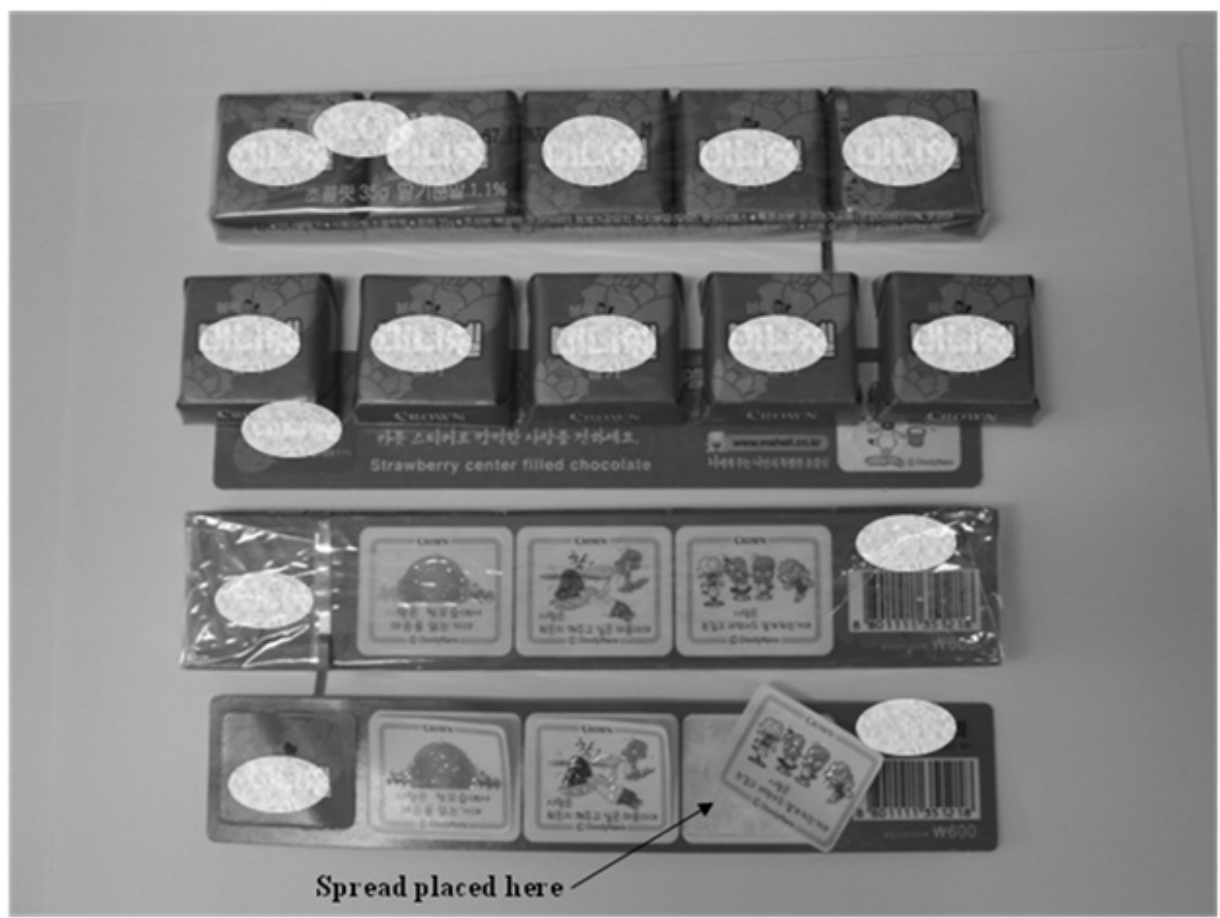

Fig. 1. Chocolate products used for infestation tests. Adhesive containing the chosen concentrations of cinnamon extract was spread onto the paper pad. 
years at $28^{\circ} \mathrm{C}$ and $70-80 \%$ relative humidity with a photoperiod of 16:8 h (L: D) in our laboratory on an artificial diet modified from that of Silhacek and Miller (1972). The modified diet consisted of wheat bran $(800 \mathrm{~g})$, yeast (200 g), glycerol (600 ml), methyl p-hydroxybenzoate $(2 \mathrm{~g})$, and sorbic acid $(2 \mathrm{~g})$.

The dried bark of Cinnamonum cassia was purchased from a medicinal materials market in Seoul, and was ground into powder. A hundred grams of the powder were mixed in a flask with $450 \mathrm{ml}$ distilled water and $450 \mathrm{ml}$ ethanol, then steam-distilled for 4 hours in a modified Donald apparatus (Donald et al., 1982). The solvent was evaporated under a vacuum in a rotary evaporator. The ethanol extract obtained was 16-20 brix.

The cinnamon extract was mixed with the adhesive used to affix the sticker to the paper pad, which consisted of $38-42 \%$ water, $25-36 \%$ 2-ethylhexyl acrylate, $3-10 \%$ methyl methacrylate, and $0.5-3 \%$ acrylic acid to 0.01 , 0.02 and $0.025 \mathrm{mg} / \mathrm{ml}$. As the adhesive loses its stickiness when the concentration exceeds $0.03 \mathrm{mg} / \mathrm{ml}$, we selected $0.025 \mathrm{mg} / \mathrm{ml}$ as the highest concentration to be tested. The desired concentration of the extract containing 0.055 $\mathrm{mg}$ of adhesive was spread onto the paper pad, upon which a picture sticker was fixed. Five chocolate pieces enveloped with aluminum-coated paper were then placed on the pad and packed with a cellophane outer layer. Adhesive without the cinnamon extract was used in the control packaging. The treated products were allowed to evaporate of cinnamon extract under general distribution conditions for $0,20,30,40,60,90,120$, and 180 days. Thus, we had 32 treatment combinations (4 concentrations $\times 8$ periods).

The infestation test was conducted with two test sets: A no-choice test in a small delivery plastic box (200× $145 \times 90 \mathrm{~mm}$ ); and a quadruple-choice test in a large delivery plastic delivery box $(350 \times 240 \times 180 \mathrm{~mm})$ were suitable for the retail markets. For the small box test, 200 2nd and 3rd instar larvae were introduced into the small box containing 5 treated chocolate packages. The box was covered with cotton cloth and maintained for 20 days at $28.1^{\circ} \mathrm{C}$. The chocolate package was then examined to determine whether the package had been penetrated by the larvae of the Indian meal moth (Fig. $2)$. The test was replicated 5 times for each treatment. For the quadruple choice test, 800 2nd and 3rd larvae were introduced into the large box containing 40 chocolate packages, comprising four sets of each 10 packages. The four sets were treated with each concentration of $0,0.01,0.02$, or $0.025 \mathrm{mg} / \mathrm{ml}$ and left to stand for different storage periods. The test was replicated 6 times for each treatment.

The subjects for the odor of cinnamon extract panel test included 40 employees in the marketing department of a Seoul chocolate manufacturer. Each was given two chocolate products within the packages, with and without treatment in random order, and was asked whether they

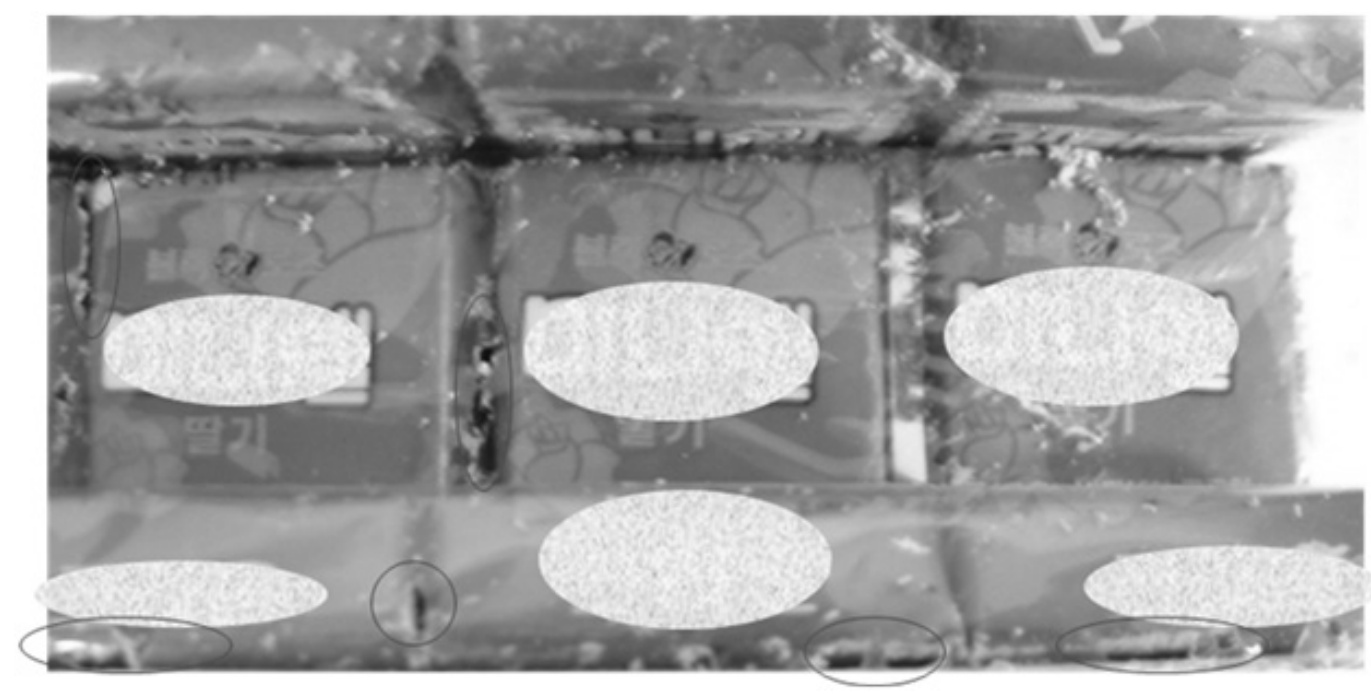

Fig. 2. Chocolate packages penetrated by the larvae of the Indian meal moths. 
could detect the treated packages and whether they would avoid them.

The effects of extract concentration on the larval infestation of chocolate were analyzed via the non-parametric Kruskal-Wallis test (SAS Institute, 2004).

\section{Results and Discussion}

Table 1 shows the infestation rates to the chocolate package by the larvae of the Indian meal moths. In the no-choice test, the treatment of adhesive with cinnamon extract protected the packages against larval infestation for up to 30 days. In the quadruple choice test, which was designed to simulate the conditions of the retail markets, where different sorts of packages are displayed for sale, the protection was maintained for a longer period, of up to 60 days. As this study was conducted under conditions of unrealistically high larval density, the protection of chocolate packages would be maintained for a period longer than 60 days; the treatment of adhesive with cinnamon extracts may prove a reliable method.
The marketing period of chocolate is approximately 3-9 months in Korea. Thus, the protection of the chocolate packages for 60 or more days is not satisfactory for manufacturers. Some other combinations of adhesives and cinnamon extracts might render a higher concentration of cinnamon extracts feasible. Further studies into this subject are clearly warranted.

The panel study demonstrated that none of the 40 subjects involved could distinguish the chocolate in a treated package from that in an untreated package, and evidenced no preference for the untreated packages. Apparently, the odor of cinnamon extract at a concentration of approximately $0.025 \mathrm{mg} / \mathrm{ml}$ of the adhesive is weak, or similar to that of the chocolate products themselves, that it cannot be discerned.

Cinnamaldehyde, a major constituent of cinnamon oil and extracts, is an antifeedant and repellent to various insect pests and acari. It can be utilized as a cream, patch, fumigant, or in direct contact treatment (Huang and Ho, 1998; Kim et al., 2006). The results of the this study demonstrate that cinnamon extracts can be added to the adhesive used to affix a picture stickers to the paper

Table 1. Percentage of chocolate packages infested after treatment with differing concentrations of cinnamon extract by Plodia interpunctella larvae

\begin{tabular}{|c|c|c|c|c|c|c|c|}
\hline \multirow{3}{*}{ Test set } & \multirow{3}{*}{$\begin{array}{c}\text { Treatment } \\
\text { period (days) }\end{array}$} & \multicolumn{4}{|c|}{$\%$ infestation $\pm \mathrm{SD}$} & \multirow{3}{*}{$x^{2}$} & \multirow{3}{*}{$P$} \\
\hline & & \multicolumn{4}{|c|}{ Concentration of extract $(\mathrm{mg} / \mathrm{ml})$} & & \\
\hline & & 0.0 & 1.0 & 2.0 & 2.5 & & \\
\hline \multirow{8}{*}{$\begin{array}{l}\text { No choice } \\
\text { test }\end{array}$} & 0 & $64.0 \pm 21.91$ & $24.0 \pm 8.94$ & 0 & 0 & 18.43 & 0.0004 \\
\hline & 20 & $80.0 \pm 14.14$ & $32.0 \pm 10.95$ & 0 & 0 & 18.49 & 0.0003 \\
\hline & 30 & 100 & $36.0 \pm 16.73$ & $4.0 \pm 8.94$ & 0 & 17.68 & 0.0005 \\
\hline & 40 & 100 & $52.0 \pm 17.89$ & $20.0 \pm 14.14$ & $8.0 \pm 10.95$ & 16.72 & 0.0008 \\
\hline & 60 & 100 & $60.0 \pm 14.14$ & $24.0 \pm 8.94$ & $12.0 \pm 10.95$ & 17.46 & 0.0006 \\
\hline & 90 & 100 & $76.0 \pm 16.73$ & $32.0 \pm 10.95$ & $16.0 \pm 8.94$ & 17.24 & 0.0006 \\
\hline & 120 & 100 & 100 & $40.0 \pm 14.14$ & $24.0 \pm 8.94$ & 17.60 & 0.0005 \\
\hline & 180 & 100 & 100 & $52.0 \pm 10.95$ & $32.0 \pm 10.95$ & 17.87 & 0.0005 \\
\hline \multirow{8}{*}{$\begin{array}{l}\text { Quadruple choice } \\
\text { test }\end{array}$} & 0 & 100 & $15.0 \pm 8.37$ & 0 & 0 & 21.24 & $<0.0001$ \\
\hline & 20 & 100 & $18.33 \pm 4.08$ & 0 & 0 & 22.82 & $<0.0001$ \\
\hline & 30 & 100 & $25.0 \pm 10.49$ & 0 & 0 & 22.62 & $<0.0001$ \\
\hline & 40 & 100 & $31.67 \pm 9.83$ & 0 & 0 & 22.65 & $<0.0001$ \\
\hline & 60 & 100 & $41.67 \pm 4.08$ & $13.33 \pm 8.16$ & 0 & 22.05 & $<0.0001$ \\
\hline & 90 & 100 & $65.0 \pm 8.37$ & $28.33 \pm 9.83$ & $10.0 \pm 8.94$ & 21.58 & $<0.0001$ \\
\hline & 120 & 100 & $81.67 \pm 9.83$ & $36.67 \pm 5.16$ & $20.0 \pm 10.95$ & 20.92 & 0.0001 \\
\hline & 180 & 100 & 100 & $43.33 \pm 8.16$ & $28.33 \pm 9.83$ & 21.67 & $<0.0001$ \\
\hline
\end{tabular}


pads, thereby conferring protection from infestation by the Indian meal moths. The affixing of the stickers to the paper pads with cinnamon-enhanced adhesive is both safe, easy (Hong and $\mathrm{Na}$, personal observation), and effective, as shown in this study.

\section{Acknowledgements}

We gratefully acknowledge the Crown Confectionery Co. for making available the chocolate product samples and related information. This study was financially supported by the Crown Confectionery Co. and by a research grant from Korea University to JHN.

\section{Literature Cited}

Begum, K., P.V. Reddy, B.C. Leelaja, Y. Rajashekar, and S. Rajendran. 2007. Studies on insect infestation in chocolates. J.Stored Prod. Res. 43: 118-122.

Cline, L.D. 1978. Penetration of seven common flexible packaging materials by larvae and adults of eleven species of storedproduct insects. J. Econ. Entomol. 71: 726-729.

Donald, L.P., M.L. Gary, and S.K. Jr. George. 1982. Introduction to Organic Laboratory Techniques; a Contemporary Approach $2^{\text {nd }}$ ed. Saunders College, Philadelphia.

Field, P.G., Y.S. Xie, and X. Hou. 2001. Repellent effect of pea (Pisum sativum) fractions against stored-product insects. J.
Stored Prod. Res. 37: 359-370.

Huang, Y., and S.H. Ho. 1998. Toxicity and antifeedants activities of cinnamaldehyde against the grain storage insects, Tribolium castaneum (Herbst) and Sitophilus zeamais Motsch. J. Stored Prod. Res. 33, 289-298.

Highland, H.A. 1984. Insect infestation of packages. In: Baur, FJ. (Ed.), Insect Management for Food Processing. American Association of Cereal Chemists, St. Paul, MN, pp. 311-320.

Highland, H.A. 1991. Protecting packages against insects. In: Gorham JR. (Ed.), Ecology and Management of Food-Industry Pests. Association of Official Analytical Chemists, Arlington, VA, pp. 345-350.

Kim, S-I., H-K. Kim, Y.-Y. Koh, J.M. Clark and Y.- J. Ahn. 2006. Toxicity of spray and fumigant products containing cassia oil to Dermatophagoides farinae and Dermatophagoides pteronyssinus (Acari: Pyroglyphidae). Pest Manage. Sci. 62: 768-774.

Mullen, M.A., and S.V. Mowery. 2000. Insect-resistant packaging. Int. Food Hyg. 11, 13-14.

Newton, J. 1988. Insect and packaging-a review. Int. Biodeterior. 24: $175-187$.

Redwan, M.N., and G.P. Allin. 1997. Controlled-release insect repellent device. US Patent 5,688,509.

SAS Institute. 2004. SAS OnlineDoc, Version 8.01. SAS Institute, Cary, NC.

Shaaya, E., M. Kostjukovski, J. Eilberg, and C. Sukprakarn. 1997. Plant oil as fumigants and contact insecticides for the control of stored-product insects. J. Stored Prod. Res. 33: 7-15.

Silhacek, D.L., and G.L. Miller. 1972. Growth and development of the Indianmeal moth, Plodia interpunctella under laboratory massrearing conditions. Ann. Entomol. Soc. Am. 65: 1084-1087.

Watson, E., and G. Barson. 1996. A laboratory assessment of the behavioural response of Oryzaephilus surinamensis (L.) (Coleoptera: Silvanidae) to three insecticides and the insect repellent $\mathrm{N}, \mathrm{N}$ diethyl- $m$-toluamide. J. Stored Prod. Res. 32: 59-67.

(Received for publication November 17 2008;

revised November 17 2008; accepted December 16 2008) 